\title{
Effect of Basic Slag on Yield, Nutrient Status and Uptake by Paddy in Acid Soils of Karnataka, India
}

\author{
D. Mamatha*, R.C. Gowda and M.N. Shivakumara \\ Department of Soil Science and Agricultural Chemistry, College of Agriculture, University of \\ Agricultural Sciences, GKVK, Bengaluru - 560 065, Karnataka, India \\ *Corresponding author
}

\section{A B S T R A C T}

\begin{tabular}{|l|}
\hline K e y w o r d s \\
Basic slag, Lime, \\
Paddy, Yield, \\
Nutrient status, \\
Nutrient uptake \\
\hline Article Info \\
\hline $\begin{array}{l}\text { Accepted: } \\
\text { 20 January } 2018 \\
\text { Available Online: } \\
\text { 10 February } 2018\end{array}$ \\
\hline
\end{tabular}

\section{Introduction}

Rice (Oryza sativa L.) is an important cereal crop grown in India, contributing about 45 per cent to the total food grain production and staple food for more than 60 per cent of world population (Singh et al., 2013). Among rice growing countries, India has the largest area $(44.11 \mathrm{~m}$ ha) with a production and productivity of $105.48 \mathrm{~m} \mathrm{t}$ and $2.39 \mathrm{t} \mathrm{ha}^{-1}$ respectively. In Karnataka, rice is grown in an area of $1.33 \mathrm{~m}$ ha with an annual production of $3.54 \mathrm{~m} \mathrm{t}$ having average yield of $2.67 \mathrm{t} \mathrm{ha}^{-1}$ (MoA, 2016). Rice crop has got wide physical adaptability. Hence, it is grown on diverse soil, climatic and hydrological conditions. Demand for rice is growing every year. To sustain present self-sufficiency of food and to meet future food requirements, India has to increase rice yield per unit area. Many abiotic and biotic factors such as such as drought, soil acidity, salinity, pests, and disease, are responsible for lower yield of crops. Soil acidity is an important yield limiting abiotic factors for crop production. In India acid soils occupy about $49 \mathrm{~m}$ ha area, of which $26 \mathrm{~m}$ ha has $\mathrm{pH}$ below 5.5 and $23 \mathrm{~m}$ ha has $\mathrm{pH}$ between 5.6 and 6.5 (Panda, 1979). In 
Karnataka, nearly $9.6 \mathrm{~m}$ ha of area is acidic in nature (Ananthanarayana, 1969). Rice grown in acidic soils $(\mathrm{pH}<4.0)$ commonly encounter with several relatively severe mineral stresses. The $\mathrm{H}^{+}$associated with soil acidity has indirect effects on mineral elements in low $\mathrm{pH}$ soils so that deficiencies of $\mathrm{P}, \mathrm{Ca}, \mathrm{Mg}, \mathrm{K}$, and $\mathrm{Zn}$ and toxicities of $\mathrm{Al}$ and $\mathrm{Mn}$ commonly appear (Clark et al., 1999). In this context, use of appropriate management practices include management of soil $\mathrm{pH}$, water management, supplying essential nutrients through proper inorganic and organic nutrient sources in adequate rates, at appropriate time has become an essential component in rice production. Liming is one of the well-known soil management practices used for amelioration of acid soils. Ground lime or agricultural lime, in the form of $\mathrm{CaCO}_{3}$ or $\mathrm{CaCO}_{3}+\mathrm{MgCO}_{3}$, has been the traditional material used for liming in acid soils. Now a day some industrial byproducts such as slag's from iron and steel industries, lime sludge from paper mills, cement kiln wastes etc. are also being used as liming agents. Basic slag is one such alkaline byproduct obtained from steel industry contains $\mathrm{CaO}, \mathrm{MgO}, \mathrm{SiO}_{2}$ and micronutrients, such as copper, zinc, manganese and iron. Calcium and magnesium compounds, because of their basicity, improve soil $\mathrm{pH}$ and also serve as plant nutrients. According to Dent (1986) application of basic slag of steel industry is potential and cost effective in reducing soil acidity. The present investigation was carried out to study the amelioration capacity of basic slag and agricultural lime in acid soil and its influence on yield and nutrient uptake by paddy crop.

\section{Materials and Methods}

\section{Site description}

A field experiment was conducted during Kharif, 2014 at Alasulige village which comes under hilly zone of Karnataka (Sakleshpura taluk) to study the effect of basic slag and agricultural lime on soil properties, yield and nutrient uptake by paddy (Oryza sativa L.). The basic slag was obtained from Horsco Company, Hyderabad. Basic slag was alkaline in nature $(\mathrm{pH}$ 9.2) and contained about 24.8 per cent $\mathrm{Ca}, 10.08$ per cent $\mathrm{Mg}, 0.62$ per cent phosphorus and 8.2 percent silicon. Physicochemical properties of the experimental site are presented in Table 1.

\section{Experimental details}

The experiment was laid out in a randomized complete block design with ten treatments replicated thrice. The treatment combination include, $\mathrm{T}_{1}$ : Farmer's practice (FP-Only DAP), $\mathrm{T}_{2}: \mathrm{FP}+$ basic slag @ $2 \mathrm{t} \mathrm{ha}^{-1}, \mathrm{~T}_{3}: \mathrm{FP}$ + lime@ $2 \mathrm{tha}^{-1}, \mathrm{~T}_{4}$ : Recommended doses of NPK (RDF), $\mathrm{T}_{5}: 50 \% \mathrm{RDF}+$ basic slag @ $2 \mathrm{t}$ $\mathrm{ha}^{-1}, \mathrm{~T}_{6}: 50 \% \mathrm{RDF}+$ lime @ $2 \mathrm{t} \mathrm{ha}^{-1}, \mathrm{~T}_{7}: 75$ \% RDF + basic slag@ $2 \mathrm{t} \mathrm{ha}^{-1}, \mathrm{~T}_{8}: 75 \% \mathrm{RDF}$ + lime@ $2 \mathrm{t} \mathrm{ha}^{-1}, \mathrm{~T}_{9}: 100 \% \mathrm{RDF}+$ basic slag @ $2 \mathrm{t} \mathrm{ha}^{-1}, \mathrm{~T}_{10}: 100 \% \mathrm{RDF}+$ lime@ $2 \mathrm{t} \mathrm{ha}^{-1}$. Farmer's practice comprises of application of $250 \mathrm{~kg}$ DAP ha ${ }^{-1}$. The recommended dose of NPK for paddy is 100:50:50 kg NPK ha-1. Basic slag and lime were applied to the soil fifteen days in prior to transplanting paddy seedlings and mixed thoroughly. At the time of planting, 50 per cent of nitrogen, and 100 per cent of phosphorus and potassium were applied and mixed well with the soil and remaining nitrogen was top dressed after first weeding (30DAP).

\section{Soil and plant analysis}

Grain and straw samples collected at the time of harvest were dried at $65^{\circ} \mathrm{C}$ in a hot air oven, ground and digested in di-acid mixture (HNO3: HClO4 in 10:4) by volume and the extract was analysed for $\mathrm{P}$ and $\mathrm{K}$ contents. Phosphorus was analyzed by vanado molybdate coloured method (Piper, 1966). N estimation was done using micro-kjheldahl $\mathrm{N}$ 
distillation apparatus and $\mathrm{K}$ through flame photometer. The uptake of these nutrients by paddy crop was computed by using the following formula.

Nutrient Uptake $\left(\mathrm{kg} \mathrm{ha}^{-1}\right)=$ Nutrient concentration $(\%)$ x Biomass $\left(\mathrm{kg} \mathrm{ha}^{-1}\right) / 100$

The post-harvest soil samples were analyzed for $\mathrm{pH}$ (Jackson, 1973), organic carbon (Walkley and Black, 1934), available N (Subbiah and Asija, 1956), phosphorus, potassium, exchangeable $\mathrm{Ca}$ and $\mathrm{Mg}$ (Jackson, 1973) and DTPA extractable Fe, Mn, Cu and Zn (Lindsay and Norwell, 1978) by using standard procedures. Fisher's method of analysis of variances was adopted for statistical analysis and interpretation of the data.

\section{Results and Discussion}

\section{Effect on grain and straw yield}

Data presented in table 2 indicated that application of basic slag and lime had significant effect on grain and straw yield of paddy. The higher grain (50.32 $\mathrm{q} \mathrm{ha}^{-1}$ ) and straw yield (65.93 $\left.\mathrm{q} \mathrm{ha}^{-1}\right)$ was recorded in treatment $\mathrm{T}_{9}(100 \% \mathrm{RDF}+$ basic slag @2 t $\left.\mathrm{ha}^{-1}\right)$ followed by $\mathrm{T}_{10}(100 \% \mathrm{RDF}+$ lime @ $2 \mathrm{t}$ $\mathrm{ha}^{-1}$ ) and significantly differed with other treatments. These results demonstrated that a balanced fertilization of $\mathrm{N}, \mathrm{P}$ and $\mathrm{K}$ coupled with liming are essential to obtain higher paddy yield in acidic soils. The yield benefits from the application of basic slag and lime can be ascribed to the lime induced changes in soil environment, especially increase in soil $\mathrm{pH}$ along with the associated improvement in nutrient availability, reduced Al toxicity and many other attributes of soil fertility (Manoj Kumar et al., 2012). Vacharotayan et al., (1984) reported that liming with $\mathrm{N}$ and $\mathrm{P}$ fertilizers resulted in the $37 \%$ additional increase of paddy yield compared to liming alone. Bhat et al., (2010) reported that liming with basic slag and calcite application improved availability of plant nutrients and yield attributing parameters of mustard, but increase was more with basic slag than with calcite.

\section{Effect on nutrient uptake}

Higher total uptake of nitrogen $(101.90 \mathrm{~kg}$ $\left.\mathrm{ha}^{-1}\right)$, phosphorus $\left(20.20 \mathrm{~kg} \mathrm{ha}^{-1}\right)$ and potassium (107.46 $\mathrm{kg} \mathrm{ha}^{-1}$ ) by paddy crop were recorded in treatment $\left(\mathrm{T}_{9}\right)$ receiving 100 $\%$ RDF + basic slag@ $2 \mathrm{t} \mathrm{ha}^{-1}$ compared to all other treatments (Table 3). The lowest level of $\mathrm{N}, \mathrm{P}$ and $\mathrm{K}$ uptake was found in case of $\mathrm{T}_{1}$ (farmer's practice). Nutrient uptake is usually governed by the nutrient concentrations and dry matter yield. The absorption of nutrients depends on their ionic forms in the rhizosphere, which is influenced by soil acidity and the overall concentrations of nutrients in the soil (Masud et al., 2014). The reduction in soil acidity might have increased the $\mathrm{pH}$ and availability of $\mathrm{N}$ and ultimately its uptake by the crop (Kihanda et al., 1988). Liming increased root proliferation by reducing toxic effects of $\mathrm{Al}$ (Tang et al., 2003) and thus enhanced the uptake of $\mathrm{P}$ and $\mathrm{K}$ (Chang and Sung, 2004), which attributed in increase in the yield of paddy.

\section{Effect on soil pH and available nutrient status}

Application of basic slag and lime @ $2 \mathrm{t} \mathrm{ha}^{-1}$ has effectively increased $\mathrm{pH}$ (Fig. 1). However, the effect of lime on $\mathrm{pH}$ was slightly higher than basic slag. Increase in $\mathrm{pH}$ indicates that usefulness of basic slag as liming material for amelioration of acid soil. Further, the basic slag and lime treatments significantly increased available $P$, exchangeable $\mathrm{Ca}$ and $\mathrm{Mg}$ contents of soil. The available $\mathrm{N}$ and $\mathrm{K}$ contents did not show any significant difference between treatments (Table 4). 
Table.1 Physico-chemical properties of experimental site

\begin{tabular}{|c|c|}
\hline Soil properties & \\
\hline Textural class & Loamy sand \\
\hline B.D $\left(\mathrm{g} \mathrm{cc}^{-1}\right)$ & 1.43 \\
\hline P.D $\left(\mathrm{g} \mathrm{cc}^{-1}\right)$ & 2.42 \\
\hline $\mathrm{pH}(1: 2.5)$ & 4.92 \\
\hline $\mathrm{EC}\left(\mathrm{dSm}^{-1}\right)(1: 2.5)$ & 0.09 \\
\hline CEC $\left[\mathrm{cmol}\left(\mathrm{p}^{+}\right) \mathrm{kg}^{-1}\right]$ & 12.0 \\
\hline O.C $(\%)$ & 0.50 \\
\hline A vailable $\mathbf{N}\left(\mathrm{kg} \mathrm{ha}^{-1}\right)$ & 298 \\
\hline A vailable $\mathrm{P}_{2} \mathrm{O}_{5}\left(\mathrm{~kg} \mathrm{ha}^{-1}\right)$ & 28.5 \\
\hline A vailable $\mathrm{K}_{2} \mathrm{O}\left(\mathrm{kg} \mathrm{ha}^{-1}\right)$ & 182 \\
\hline Exchangeable $\mathrm{Ca}\left[\mathrm{cmol}\left(\mathrm{p}^{+}\right) \mathrm{kg}^{-1}\right]$ & 1.40 \\
\hline Exchangeable $\mathrm{Mg}\left[\mathrm{cmol}\left(\mathrm{p}^{+}\right) \mathrm{kg}^{-1}\right]$ & 0.60 \\
\hline DTPA extractable Fe (ppm) & 125 \\
\hline DTPA extractable Mn (ppm) & 9.40 \\
\hline DTPA extractable Zn (ppm) & 3.10 \\
\hline DTPA extractable $\mathrm{Cu}$ (ppm) & 0.84 \\
\hline
\end{tabular}

Table. 2 Influence of basic slag and lime treatments on grain and straw yield of paddy

\begin{tabular}{|l|} 
Treatments \\
\hline $\mathrm{T}_{1}: \mathrm{FP}$ (Only DAP) \\
\hline $\mathrm{T}_{2}: \mathrm{FP}+$ basic slag @ $2 \mathrm{t} \mathrm{ha}^{-1}$ \\
\hline $\mathrm{T}_{3}: \mathrm{FP}+$ lime @ $2 \mathrm{t} \mathrm{ha}^{-1}$ \\
\hline $\mathrm{T}_{4}:$ Recommended doses of NPK $(\mathrm{RDF})$ \\
\hline $\mathrm{T}_{5}: 50 \% \mathrm{RDF}+$ basic slag @ $2 \mathrm{t} \mathrm{ha}^{-1}$ \\
\hline $\mathrm{T}_{6}: 50 \% \mathrm{RDF}+$ lime @ $2 \mathrm{t} \mathrm{ha}{ }^{-1}$ \\
\hline $\mathrm{T}_{7}: 75 \% \mathrm{RDF}+$ basic slag @ $2 \mathrm{t} \mathrm{ha}^{-1}$ \\
\hline $\mathrm{T}_{8}: 75 \% \mathrm{RDF}+$ lime @ $2 \mathrm{t} \mathrm{ha}^{-1}$ \\
\hline $\mathrm{T}_{9}: 100 \% \mathrm{RDF}+$ basic slag @ $2 \mathrm{t} \mathrm{ha}^{-1}$ \\
\hline $\mathrm{T}_{10}: 100 \% \mathrm{RDF}+$ lime @ $2 \mathrm{t} \mathrm{ha}^{-1}$ \\
SE.m \pm \\
\hline CD @ $5 \%$
\end{tabular}

\begin{tabular}{|c|c|}
\hline Grain yield $\left(\right.$ qha $\left.^{-1}\right)$ & $\begin{array}{c}\text { Straw yield } \\
(\mathbf{q h a}\end{array}$ \\
\hline 39.48 & 46.94 \\
\hline 40.00 & 48.32 \\
\hline 40.02 & 50.55 \\
\hline 44.84 & 52.40 \\
\hline 40.81 & 56.25 \\
\hline 40.70 & 55.72 \\
\hline 44.19 & 60.58 \\
\hline 44.70 & 60.78 \\
\hline 50.32 & 65.93 \\
\hline 49.96 & 62.01 \\
\hline 1.7 & 3.4 \\
\hline 5.0 & 10.0 \\
\hline
\end{tabular}


Table.3 Effect of basic slag and lime treatments on nutrient uptake by paddy crop

\begin{tabular}{|c|c|c|c|c|c|c|c|c|c|}
\hline \multirow[t]{3}{*}{ Treatments } & \multicolumn{3}{|c|}{ Nitrogen } & \multicolumn{3}{|c|}{ Phosphorus } & \multicolumn{3}{|c|}{ Potassium } \\
\hline & Grain & Straw & Total & Grain & Straw & Total & Grain & Straw & Total \\
\hline & \multicolumn{9}{|c|}{$\left(\mathrm{kg} \mathrm{ha}^{-1}\right)$} \\
\hline 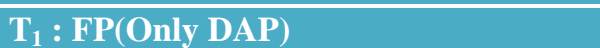 & 31.92 & 27.57 & 59.49 & 6.51 & 4.56 & 11.08 & 10.48 & 59.55 & 70.03 \\
\hline $\mathrm{T}_{2}: \mathrm{FP}+$ basic slag @ $2 \mathrm{t} \mathrm{ha}^{-1}$ & 33.33 & 30.12 & 63.45 & 6.27 & 5.10 & 11.37 & 10.16 & 63.10 & 73.26 \\
\hline $\mathrm{T}_{3}: \mathrm{FP}+$ lime @ $2 \mathrm{tha}^{-1}$ & 38.92 & 30.82 & 69.74 & 7.04 & 5.20 & 12.20 & 11.72 & 65.45 & 77.17 \\
\hline $\mathrm{T}_{4}:$ Recommended dose of NPK (RDF) & 48.98 & 34.66 & 83.64 & 10.31 & 6.22 & 16.52 & 13.84 & 72.74 & 86.59 \\
\hline $\mathrm{T}_{5}: 50 \% \mathrm{RDF}+$ basic slag @ $2 \mathrm{t} \mathrm{ha}^{-1}$ & 39.17 & 34.79 & 73.96 & 7.04 & 6.47 & 13.52 & 11.92 & 73.22 & 85.14 \\
\hline $\mathrm{T}_{6}: 50 \% \mathrm{RDF}+$ lime @ $2 \mathrm{t} \mathrm{ha}^{-1}$ & 39.46 & 35.12 & 74.59 & 7.74 & 5.48 & 13.22 & 11.36 & 74.38 & 85.75 \\
\hline $\mathrm{T}_{7}: 75 \% \mathrm{RDF}+$ basic slag @ $2 \mathrm{t} \mathrm{ha}^{-1}$ & 49.03 & 39.53 & 88.57 & 10.37 & 7.31 & 17.69 & 13.17 & 82.57 & 95.75 \\
\hline $\mathrm{T}_{8}: 75 \% \mathrm{RDF}+$ lime @ $2 \mathrm{t} \mathrm{ha}^{-1}$ & 45.09 & 38.77 & 83.86 & 9.28 & 6.89 & 16.18 & 11.37 & 82.97 & 94.34 \\
\hline $\mathrm{T}_{9}: 100 \% \mathrm{RDF}+$ basic slag @ $2 \mathrm{t} \mathrm{ha}^{-1}$ & 56.38 & 45.52 & 101.90 & 11.61 & 8.59 & 20.20 & 15.79 & 91.66 & 107.46 \\
\hline $\mathrm{T}_{10}: 100 \% \mathrm{RDF}+$ lime @ 2t ha ${ }^{-1}$ & 55.62 & 41.86 & 97.48 & 10.82 & 6.86 & 17.68 & 13.26 & 84.98 & 98.24 \\
\hline SE.m \pm & 2.80 & 1.73 & 3.90 & 0.45 & 0.22 & 0.81 & 0.54 & 3.89 & 6.16 \\
\hline CD@ $9 \%$ & 8.32 & 5.13 & 11.6 & 1.34 & 0.65 & 2.41 & 1.61 & 11.55 & 18.32 \\
\hline
\end{tabular}

Table.4 Effect of basic slag and lime treatments on available nutrient status of soil after harvest of paddy crop

\begin{tabular}{|c|c|c|c|c|c|c|c|c|c|}
\hline \multirow[t]{2}{*}{ Treatments } & $\begin{array}{c}\text { Avail. } \\
\mathbf{N}\end{array}$ & $\begin{array}{l}\text { Avail. } \\
\mathrm{P}_{2} \mathrm{O}_{5}\end{array}$ & $\begin{array}{c}\text { Avail. } \\
\mathrm{K}_{2} \mathrm{O}\end{array}$ & $\begin{array}{c}\text { Exch. } \\
\text { Ca }\end{array}$ & $\begin{array}{c}\text { Exch. } \\
\text { Mg }\end{array}$ & Fe & Mn & $\mathrm{Cu}$ & $\mathbf{Z n}$ \\
\hline & \multicolumn{3}{|c|}{$\left(\mathrm{kg} \mathrm{ha}^{-1}\right)$} & \multicolumn{2}{|c|}{$\left(\operatorname{cmol}\left[p^{+}\right] k^{-1}\right)$} & \multicolumn{4}{|c|}{$\left(\mathrm{mg} \mathrm{kg}^{-1}\right)$} \\
\hline$T_{1}:$ FP (Only DAP) & 219.2 & 27.4 & 151.2 & 1.50 & 0.7 & 127.3 & 11.2 & 3.32 & 0.87 \\
\hline $\mathrm{T}_{2}: \mathrm{FP}+$ basic slag@ $2 \mathrm{tha}^{-1}$ & 224.7 & 29.9 & 123.2 & 1.67 & 1.0 & 115.6 & 10.9 & 3.52 & 0.94 \\
\hline $\mathrm{T}_{3}: \mathrm{FP}+$ lime @ $2 \mathrm{t} \mathrm{ha}^{-1}$ & 219.5 & 26.7 & 132.0 & 2.00 & 1.0 & 110.1 & 8.9 & 3.28 & 0.90 \\
\hline $\mathrm{T}_{4}:$ Recommended doses of NPK (RDF) & 229.2 & 30.0 & 138.7 & 1.53 & 0.6 & 137.3 & 15.7 & 3.45 & 0.92 \\
\hline $\mathrm{T}_{5}: 50 \%$ RDF+ basic slag @ $2 \mathrm{t} \mathrm{ha}^{-1}$ & 238.8 & 27.6 & 138.4 & 1.97 & 1.1 & 118.3 & 10.5 & 3.52 & 0.95 \\
\hline $\mathrm{T}_{6}: 50 \% \mathrm{RDF}+$ lime @ $2 \mathrm{tha}^{-1}$ & 228.3 & 29.7 & 140.0 & 1.83 & 1.0 & 117.4 & 9.2 & 3.26 & 1.00 \\
\hline $\mathrm{T}_{7}: 75 \% \mathrm{RDF}+$ basic slag @ $2 \mathrm{t} \mathrm{ha}^{-1}$ & 227.7 & 31.0 & 147.2 & 2.63 & 1.1 & 119.8 & 10.4 & 3.53 & 0.97 \\
\hline $\mathrm{T}_{8}: 75 \% \mathrm{RDF}+$ lime @ $2 \mathrm{tha}^{-1}$ & 237.9 & 29.9 & 140.0 & 2.47 & 1.0 & 114.1 & 9.0 & 3.36 & 0.93 \\
\hline $\mathrm{T}_{9}: 100 \% \mathrm{RDF}+$ basic slag @ $2 \mathrm{t} \mathrm{ha}^{-1}$ & 228.3 & 33.8 & 132.0 & 2.33 & 1.2 & 109.5 & 10.4 & 3.31 & 1.02 \\
\hline $\mathrm{T}_{10}: 100 \% \mathrm{RDF}+$ lime @ 2t ha ${ }^{-1}$ & 217.4 & 30.5 & 132.8 & 2.17 & 1.1 & 104.3 & 9.4 & 3.28 & 0.97 \\
\hline SE.m \pm & 9.5 & 1.1 & 5.8 & 0.11 & 0.07 & 4.6 & 0.7 & 0.2 & 0.04 \\
\hline CD@5\% & NS* & 3.2 & NS* & 0.32 & 0.22 & 13.6 & 2.0 & NS* & NS* \\
\hline
\end{tabular}


Fig.1 Effect of basic slag and lime treatments on soil $\mathrm{pH}$

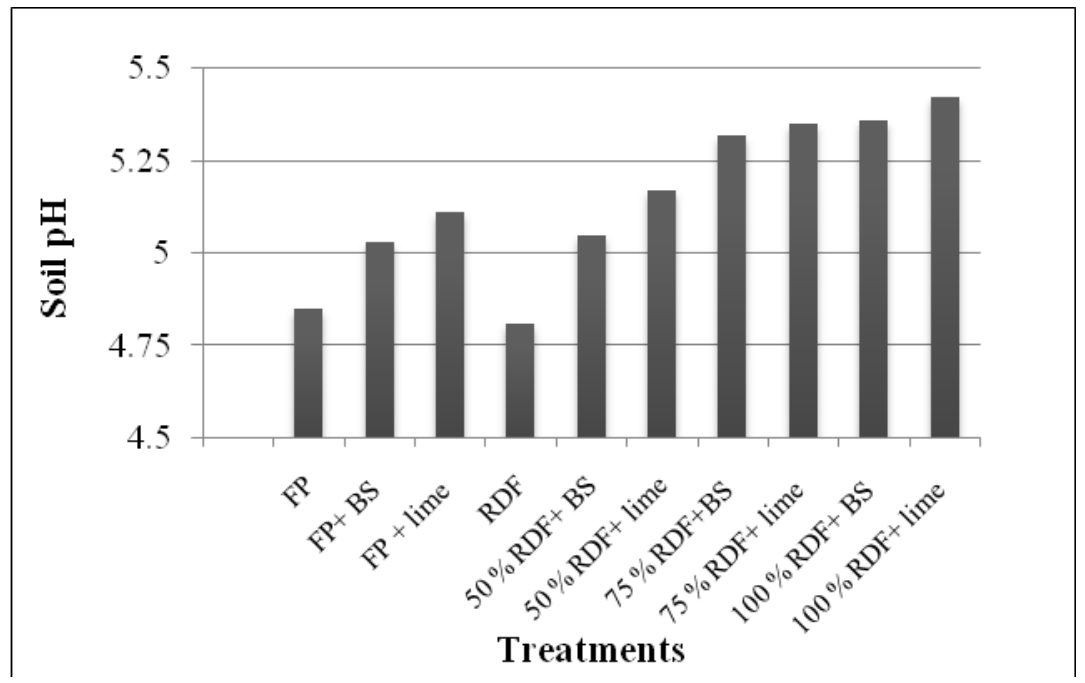

*FP- Farmer's practice; RDF- Recommended Dose of NPK; BS- Basic slag; BS\& lime applied @ 2tha ${ }^{-1}$

Higher available status of phosphorus (33.8 $\left.\mathrm{kg} \mathrm{ha}^{-1}\right)$ after harvest was recorded in $\mathrm{T}_{9}(100$ \% RDF+ basic slag @ $\left.2 \mathrm{t} \mathrm{ha}^{-1}\right)$. This treatment was significantly differed from rest of the treatments except $\mathrm{T}_{7}$ (75\% RDF+ basic slag @ $\left.2 \mathrm{t} \mathrm{ha}^{-1}\right)$. The highest exchangeable $\mathrm{Ca}$ $\left(2.63 \mathrm{cmol}\left[\mathrm{p}^{+}\right] \mathrm{kg}^{-1}\right)$ and exchangeable $\mathrm{Mg}$ $\left(1.2 \mathrm{cmol}[\mathrm{p}+] \mathrm{kg}^{-1}\right)$ contents were found in treatment $\mathrm{T}_{7}$ and $\mathrm{T}_{9}$, respectively compared to all other treatments. The increase in available $\mathrm{P}$ content of the soil might be due to increased soil $\mathrm{pH}$ upon liming. The basic slag and lime upon dissolution released a large amount of $\mathrm{Ca}$ and $\mathrm{Mg}$ which neutralized soil acidity by displacing the aluminum, hydrogen and iron ions, which are prevalent in acid soils thus increasing soil $\mathrm{pH}$ and consequent increase in $\mathrm{P}, \mathrm{Ca}$ and $\mathrm{Mg}$ in soil. Since basic slag contains appreciable amounts of $\mathrm{P}$ that could contribute to the increasing trend in available $\mathrm{P}$ in basic slag treatments over lime treatments. Takahashi et al., (1990) reported the silicate ion can replace and release the phosphate ion fixed in the soil, thus increasing the amount of phosphate available to the plant. This is in agreement with the result of Ali and Shahram (2007) who reported that converter slag proportionately enhances the $\mathrm{P}$ availability in acid soil.
Application of basic slag and lime significantly decreased the levels of DTPA extractable $\mathrm{Fe}$ and $\mathrm{Mn}$ contents whereas, DTPA extractable $\mathrm{Cu}$ and $\mathrm{Zn}$ contents of the soil differed non-significantly.

Similar effect of liming materials in reducing levels $\mathrm{Fe}$ and $\mathrm{Mn}$ content in soil has reported by Takac et al., 2009 and Tang et al., 2003.

Results of the study indicated a promising potential for basic slag to be used as an alternative to lime for amelioration of acid soils. Results also showed that the combined application of basic slag or lime @ $2 \mathrm{t} \mathrm{ha}^{-1}$ along with RDF (NPK) was more beneficial in improving available nutrient of status of acid soil and thus enhancing crop yield and uptake of nutrient by paddy plants.

\section{References}

Ali, M. T., and Shahram, S. H. 2007. Converter Slag as a Liming Agent in the Amelioration of Acidic Soils. Int. J. Agric. Biol. 9: 715720.

Ananthanarayana, R. 1969. Studies On Lime Requirement Of Acid Soils Of South Kanara District, Manoj-Kumar, Hazarika S., Rajkhowa D.J., Ramesh T., Bordoloi L. J. 
And Krishnappa R., 2012, Integrated Nutrient Management For Enhancing Maize Productivity On An Acid Alfisol Of Meghalaya, India. In: Compendium of Abstracts, $8^{\text {th }}$ Psilph, Uas, Bangalore Pp: 323-324.Mysore, M.Sc. Thesis.

Bhat, Manik Chandra Kundu, Gora Chand Hazra, Gour Hari Santra and Biswapati Mandal, 2010. Rehabilitating Acid Soils for Increasing Crop Productivity through LowCost Liming Material India. AmericanEurasian I. Agric. Environ. Sci., 20: 43464353.

Chang, C. S., and Sung, J. M. 2004. Nutrient uptake and yield responses of peanuts and rice to lime and fused magnesium phosphate in an acid soil. Field Crops Res., 89: 319-325

Clark, R. B., Zobel, R. W., and Zeto, S. K. 1999. Effects of mycorrhizal fungus isolates on mineral acquisition by Panicum virgatum in acidic soil. Mycorrhiza, 9(3): 167-176.

Dent, D. (1986) In "Acid Sulfate Soils: A Baseline for Research and Development". Ilri Publication 39, Wageningen, Pp: 58.

Jackson, M. L. 1973, Soil Chemical Analysis, Prentice Hall of India Pvt. Ltd., New Delhi

Kihanda, F.M., Wood, M., and Onell, M. K. 1998. Effect of Lime, Farmyard Manure and NP Fertilizers On Maize Yield And Soil Chemical Characteristics In An Ando-Humic Nitosol Of Central Kenya. Proc. Eastern Southern Africa Regional Maize Conference. Adis Ababa (Ethiopia) Sep. 21-25.

Lindsay, W, L., and Norwell, W, A. 1978. Development of a DTPA soil test for $\mathrm{Zn}, \mathrm{Fe}$, $\mathrm{Mn}$ and Cu. Soil Sci. Am. J., 42: 421-428.

Manoj Kumar, Hazarika S., Rajkhowa D.J., Ramesh T., Bordoloi L. J., and Krishnappa R. 2012. Integrated nutrient management for enhancing maize productivity on an acid alfisol of Meghalaya, India. In: Compendium of Abstracts, $8^{\text {th }}$ PSILPH, UAS, Bangalore pp: 323-324.
Masud, M. M., Li Jiu-Yu and Xu Ren-Kou, 2014. Use of alkaline slag and crop residue biochars to promote base saturation and reduce acidity of an acidic ultisol. Pedosphere, 24 (6): 791-798.

Ministry Of Agriculture, 2016. Crop Statistics.

Panda, N. 1979. Fertilizer Management In Acid Soils For Increased Efficiency. Fert. News, 24: $75-83$

Piper, C.S. 1966. Soil and Plant Analysis, Hans Publishers Bombay.

Singh, Y.V., Dhar, D. W., and Agarwal, B. 2013. Influence of Organic Nutrient Management on Basmati Rice (Oryza Sativa) Wheat (Triticum Aestivum) Green Gram (Vigna Radiata) Cropping System. Indian J. Agron., 56(3): 169-175.

Subbaiah and Asija, C.S. 1956. A Rapid Method for Estimation of Available Nitrogen. Curr. Sci., 25: 81-85.

Takac, P., Szabova, T., Kozakova, L., and Benkova, M. 2009. Heavy metals and their bioavailability from soils in the long-term polluted Central Spis region of SR. Pl. Soil Environ., 55: 167-172.

Takahashi, E., Ma, J. F., and Miyake, Y. 1990. The Possibility of Silicon as an Essential Element for Higher Plants. Comments Agric. Food Chem., 2: 99-122.

Tang, C., Rengel, Z., Diatloff, E., and Gazey, C. 2003. Response of wheat and barley to liming on sandy soil with subsoil acidity. Field Crops Res. 80: 235-244

Vacharotayan, S., Attanandana, T., and Vicharnsorn, P. 1984. Acid Sulfate Soils: Their Characteristics, Genesis, Amelioration and Utilization. In: Soil Fert. Tech. Res., Pp: 1.

Walkley, A. J., and Black, C. A. 1934. An Examination of the Method for Determining Soil Organic Matter and a Proposed Modification of the Chromic Acid Titration Method. Soil Sci., 37: 29-38.

\section{How to cite this article:}

Mamatha, D., R.C. Gowda and Shivakumara, M.N. 2018. Effect of Basic Slag on Yield, Nutrient Status and Uptake by Paddy in Acid Soils of Karnataka, India. Int.J.Curr.Microbiol.App.Sci. 7(02): 2286-2292. doi: https://doi.org/10.20546/ijcmas.2018.702.276 